\title{
AC 2007-1681: MODELS OF NANOSCALE PHENOMENA AS TOOLS FOR ENGINEERING DESIGN AND SCIENCE INQUIRY
}

Shanna Daly, Purdue University

Lynn Bryan, Purdue University 


\title{
Models of Nanoscale Phenomena as Tools for Engineering Design and Science Inquiry
}

\begin{abstract}
One of the central goals of the National Center for Learning and Teaching Nanoscale Science and Engineering (NCLT) focuses on integrating concepts of nanoscale phenomena into middleand high-school curricula. To this end, it becomes especially important to utilize models and modeling for instructional purposes. Teachers' conceptions on the use of models for teaching nanoscale concepts were investigated during a two-week professional development workshop led by the NCLT. Workshop activities aimed to broaden teachers' conceptions on the utility of models for design- and inquiry-based instruction. While teachers expanded their views, their selected nanoscale science and engineering models lacked the design and inquiry components that we hoped to achieve. This information facilitates refinements to our modeling activities for future professional development workshops. Ultimately, we aim to provide teachers with the support they need to use models of nanoscale phenomena as tools for engineering design and science inquiry.
\end{abstract}

\section{Introduction}

Increased federal funding of nanotechnology-related research and development ${ }^{1}$ raises questions concerning the preparedness of future engineers and scientists. As estimated by the National Science Foundation, two million workers will be needed to support nanotechnology industries worldwide within 15 years. ${ }^{2}$ It is necessary for the science education system to prepare students for this job market. Research has shown that many students opt out of science-related careers before they enter college, ${ }^{3}$ thus the incorporation of nanotechnology concepts into middle- and high-school curricula becomes important.

These recent initiatives for teaching nanoscale concepts to younger students have strengthened the push for incorporating engineering into the K-12 classroom. Engineering in the K-12 curricula advances student learning and bridges classroom lessons to real-world experiences. ${ }^{4,5}$ The United States' investment made in future nanotechnology developments requires a reformed educational program for preparing students for engineering, science, and technology careers. ${ }^{6}$ The incorporation of nanoscale concepts into middle- and high-school curricula can contribute to these initiatives.

Research has demonstrated that students of science may gain deeper conceptual understandings when they are able to build and manipulate models of science phenomena. ${ }^{7}$ In addition, there is a consensus among scientists, engineers, and science and engineering educators in the field of nanoscale phenomena that education of nanoscale science, engineering, and technology concepts relies on models and modeling. ${ }^{8,9}$ Considering the process of creating models to represent nanoscale phenomena as a design task, students can develop this high-level thinking and engineering skill of design while improving their understanding of nanoscale phenomena. Additionally, models can be used for inquiry tasks, allowing students to develop their skills of investigation, also a necessary engineering skill. Utilizing model design and inquiry-based models in the education of nanoscale concepts relies upon teachers. 
The NCLT hosted two two-week professional development workshops during the summer of 2006, which included activities for teachers that demonstrated how models could be used beyond traditional "show-and-tell" types. During the course of these workshops, teachers completed a series of activities that allowed them and us to investigate their conceptions of models in science and engineering instruction.

As teachers' knowledge mediates their classroom instruction, it follows that their conceptions of models and the utility of models will mediate their use of models in the classroom. It is incumbent upon engineering educators, therefore, to understand teachers' conceptions of models. In this study, we are interested specifically in teachers' conceptions of models as they relate to nanoscale science and engineering education. Through a design-based framework, we hope to create a professional development program that supports teachers in utilizing models to a fuller potential.

\section{Background}

\section{Defining Models}

Models have been defined as representations of ideas, objects, events, processes, or systems, ${ }^{10}$ but these representations should not be perceived as "right answers"; they are the methods and products of science. ${ }^{11}$ As the act of science itself creates, manipulates, and uses models to better understand phenomena, models should be a major learning and teaching tool in science education. ${ }^{10}$

The word "model" has very broad definitions. As such, typologies provide a more concrete way to discuss the variety of model classifications and their functions. For example, some researchers define models in terms of the distinction between expressed versus mental models. Expressed models are representations witnessed in the form of an action, speech, writing, drawing, structure, or any other symbolic form, as opposed to mental models which lack a communication aspect. ${ }^{10}$ Expressed models can influence mental models and mental models can become expressed models through a communication component. Gilbert and Boulter defined consensus models as expressed models that have attained social acceptance. ${ }^{10}$ They further categorized these expressed and consensus models into the general categories of historical (models used in historical contexts), curricular (consensus models used in science curriculum), teaching (models developed to assist in understanding curricular models and the phenomena they represent), and hybrid (models that merge characteristics of distinct consensus models for inquiry).

Boulter and Buckley created a thorough typology, in which they not only define models types, but also further classify them as quantitative or qualitative, static or dynamic, and deterministic or stochastic. ${ }^{12}$ These further qualities are not necessarily a function of the model, but of the decision made in its construction, use, and presentation. Table 1 displays the model typology including descriptions presented by Boulter and Buckley, modified slightly by removing categories that did not specifically relate to this research. 
Table 1: Boulter and Buckley Model Types ${ }^{10}$ (adapted)

\begin{tabular}{|c|c|c|c|c|c|c|c|}
\hline & \multicolumn{3}{|c|}{ Qualitative } & \multicolumn{3}{|c|}{ Quantitative } \\
\hline & & Static & $\begin{array}{c}\text { Dynamic: } \\
\text { Deterministic }\end{array}$ & $\begin{array}{l}\text { Dynamic: } \\
\text { Stochastic }\end{array}$ & $\begin{array}{l}\text { Dynamic: } \\
\text { Stochastic }\end{array}$ & $\begin{array}{c}\text { Dynamic: } \\
\text { Deterministic }\end{array}$ & Static \\
\hline \multirow{5}{*}{$\begin{array}{l}\frac{0}{0} \\
\sum_{0}^{0} \\
\frac{0}{00} \\
.0\end{array}$} & $\begin{array}{l}\text { Concrete } \\
\text { Material }\end{array}$ & 3D Model & $\begin{array}{l}\text { 3D models } \\
\text { that move }\end{array}$ & $\begin{array}{l}\text { Physical } \\
\text { simulations }\end{array}$ & & $\begin{array}{l}\text { Working } \\
\text { scale replicas }\end{array}$ & $\begin{array}{l}\text { Scale } \\
\text { Models }\end{array}$ \\
\hline & $\begin{array}{l}\text { Visual } \\
\text { Pictorial }\end{array}$ & $\begin{array}{l}\text { Diagram } \\
\text { Drawing }\end{array}$ & $\begin{array}{l}\text { Sequenced } \\
\text { diagrams } \\
\text { Animations }\end{array}$ & & $\begin{array}{l}\text { Graphical } \\
\text { displays }\end{array}$ & $\begin{array}{l}\text { Video of live } \\
\text { phenomena }\end{array}$ & Photographs \\
\hline & $\begin{array}{l}\text { Verbal } \\
\text { Written/ Oral }\end{array}$ & $\begin{array}{l}\text { Analogy } \\
\text { Description } \\
\text { Metaphor }\end{array}$ & & & & & $\begin{array}{l}\text { Description } \\
\text { with size or } \\
\text { distance }\end{array}$ \\
\hline & $\begin{array}{l}\text { Mathematical } \\
\text { Formulaic }\end{array}$ & & & & Formulae & $\begin{array}{l}\text { Formulae } \\
\text { Computer } \\
\text { simulations }\end{array}$ & $\begin{array}{l}\text { Equations } \\
\text { Chemical } \\
\text { formulae }\end{array}$ \\
\hline & $\begin{array}{l}\text { Gestural } \\
\text { Bodily }\end{array}$ & $\begin{array}{l}\text { Showing } \\
\text { Positions }\end{array}$ & $\begin{array}{l}\text { Acting out } \\
\text { set } \\
\text { movements }\end{array}$ & $\begin{array}{l}\text { Hand } \\
\text { gestures }\end{array}$ & & $\begin{array}{l}\text { Gesturing } \\
\text { relative } \\
\text { behaviors }\end{array}$ & $\begin{array}{l}\text { Showing } \\
\text { size }\end{array}$ \\
\hline \multirow{5}{*}{ 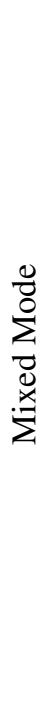 } & $\begin{array}{l}\text { Gestural } \\
\text { Bodily }\end{array}$ & $\begin{array}{l}\text { Showing } \\
\text { positions } \\
\text { with talk }\end{array}$ & $\begin{array}{l}\text { Acting out } \\
\text { with talk }\end{array}$ & $\begin{array}{l}\text { Hand } \\
\text { gestures } \\
\text { with talk }\end{array}$ & & $\begin{array}{l}\text { Gesturing } \\
\text { behavior } \\
\text { with } \\
\text { quantities } \\
\text { described }\end{array}$ & $\begin{array}{l}\text { Showing } \\
\text { size with } \\
\text { talk }\end{array}$ \\
\hline & $\begin{array}{l}\text { Mathematical } \\
\text { Formulaic }\end{array}$ & & & & & $\begin{array}{l}\text { Computer } \\
\text { simulations }\end{array}$ & $\begin{array}{l}\text { Equations } \\
\text { with } \\
\text { diagrams }\end{array}$ \\
\hline & $\begin{array}{l}\text { Verbal } \\
\text { Written/ Oral }\end{array}$ & $\begin{array}{l}\text { Analogy } \\
\text { with } \\
\text { drawing }\end{array}$ & & & & & $\begin{array}{l}\text { Description } \\
\text { with size } \\
\text { and gesture }\end{array}$ \\
\hline & $\begin{array}{l}\text { Visual } \\
\text { Pictorial }\end{array}$ & $\begin{array}{l}\text { Diagram } \\
\text { with labels }\end{array}$ & $\begin{array}{l}\text { Animation } \\
\text { with verbal }\end{array}$ & & $\begin{array}{l}\text { Graphical } \\
\text { display }\end{array}$ & $\begin{array}{l}\text { Video with } \\
\text { verbal }\end{array}$ & $\begin{array}{l}\text { Photos with } \\
\text { labels }\end{array}$ \\
\hline & $\begin{array}{l}\text { Concrete } \\
\text { Material }\end{array}$ & $\begin{array}{l}\text { 3D model } \\
\text { with labels }\end{array}$ & & $\begin{array}{l}\text { Physical } \\
\text { simulation/ } \\
\text { labels }\end{array}$ & & $\begin{array}{l}\text { Working } \\
\text { scale replica } \\
\text { with verbals }\end{array}$ & $\begin{array}{l}\text { Being an } \\
\text { object with } \\
\text { verbals }\end{array}$ \\
\hline
\end{tabular}

All types of models play a significant role in science education; however, this study focused on expressed models in the form of two- and three-dimensional physical representations. These would include concrete material, visual pictorial, gestural bodily, or any combination of those three according to Boulter and Buckley. ${ }^{12}$ In the course of this paper, these types of models will be generally referred to as two- and three-dimensional physical representations, and will be viewed according to the adapted Boulter and Buckley categorization.

\section{Models in Science and Engineering Education}

Models of all types are important to science education; they can make difficult phenomena easier to conceptualize as students have a visible representation. Additionally, the field of science utilizes models in processes of theory-development and scientific thinking, thus teaching students about science without using methods of science seems disconnected. ${ }^{7,11,13}$ The use of 
physical representation models are especially important in the instruction of nanoscale science and engineering, as nanoscale phenomena cannot be explored by students via photographs, light microscopes, or demonstrations; only the resulting micro- or macroscopic effects can be witnessed. Abstract and non-observable phenomena have been shown to be best taught with multiple models of the same phenomenon. ${ }^{13}$ Each model may represent the phenomenon in a different way or emphasize a different attribute. This variety allows students to gather multiple pieces of information in constructing their own mental models of the phenomenon. The notdirectly-observable nature of nanoscale phenomena and the reliance on models of real-world processes of nanotechnology development makes the creation of two- and three-dimensional physical representation models essential for students' understanding of nanoscale science and engineering concepts and the nature of nanoscale science and engineering.

\section{Student Difficulties with Models}

Studies have shown that students have a number of difficulties understanding the role of models in science as well as the meaning of models presented in their classes. ${ }^{7,13,14}$ Some learners memorized the model instead of understanding the science concept it represented. ${ }^{7,13,16}$ The boundaries between the model and reality were often difficult for students to understand ${ }^{14}$ as were applications of the models within different contexts. ${ }^{15}$ Grosslight defined three levels of model understanding, where those who fell in the lowest level believed in a one-to-one correspondence between models and reality. ${ }^{16}$ Those in the middle level understood that correspondence was not one-to-one, but thought models were real-world objects, not representations of ideas. Those in the highest level were experts on modeling because they understood that models should be multiple, are thinking tools, and can be purposely manipulated to meet certain needs. Most students up to the tenth grade had a level-one or between level-one and level-two understanding of models. This lack of understanding by students may have root in the ways models are presented by teachers ${ }^{11}$. Because of the strong influence teachers have on student conceptions of models and the phenomena models represent, it is important to understand the considerations teachers make in choosing models and the contexts in which they plan to use them.

\section{Teachers and Model Selection}

The literature suggests some criteria that teachers should consider when choosing a model to use in their instruction. They should select models that enhance investigation, understanding, and communication. ${ }^{11}$ Students respond positively when they feel a sense of ownership in a model. ${ }^{7}$ This ownership is most evident in student-generated models. Other criteria that science education researchers recommend are models easily understood by students, as well as those that are memorable, familiar, and logical. ${ }^{11,17}$ Beyond the model itself, the difficulty of the concept being represented by the model and the prior knowledge and ability of the students are important criteria. $^{13,17}$ While teaching and learning science often utilizes models and modeling activities, the priority teachers place on using them as scientists and engineers use them, i.e., as tools for design and inquiry, is unknown.

\section{Models and Design}

Not only can engineering be integrated into curricula because of nanotechnology's interdisciplinary nature, but also student-designed models of nanoscale phenomena add an additional dimension of engineering practice. Design is a skill of primary importance to 
engineers, ${ }^{18}$ and requires a high level of cognition. ${ }^{19}$ The design of models as representations or tools for manipulation is a skill of scientists and engineers in which students should have ample practice. Within the context of nanoscale phenomena, the NCLT professional development team emphasized inquiry and design in the use of physical representation models.

\section{Rationale}

Models play an important role in the education of nanoscience, thus lessons, activities, and discussions on models and modeling constituted a large portion of two summer 2006 NCLT professional development workshops. Because teachers are in the position to facilitate and enhance students' understanding of models and modeling, the two-week long workshops focused on nanoscale science, engineering, and technology concepts as well as supporting the implementation of teaching nanoscale phenomena into the middle- and high- school science curricula. To this end, it is incumbent upon science and engineering educators to know what teachers conceptions are of models and their utility. This study focused on the role of models in nanoscale science education as part of the NCLT workshops. Our study was guided by the following research questions:

1. What are teachers' conceptions of models and their utility? How do their conceptions of models compare to their conceptions of models of nanoscale phenomena?

2. What models of nanoscale phenomena do teachers find to potentially incorporate into their classrooms?

3. How does the structure of the workshop support teachers' understanding and use of nanoscale phenomena models in their classroom?

\section{Research Methods}

\section{Design}

This study is part of a larger design-based research project conducted by the NCLT professional development team. Professional development workshops on nanoscale phenomena will occur at several universities each summer for the next three years. The implementation structure for NCLT professional development lends itself to a design-based research framework which aims to "bring design and research activities into tight relation to advance our understanding of learning-related educational phenomena." 20

This particular study focused on science teachers' pedagogical understanding of models and the use of models in their classroom, with emphasis on models of nanoscale phenomena. Formative evaluation data informed not only research findings, but also the iterative cycle of design, implementation and redesign of the intervention (i.e., the professional development instruction).

\section{Participants}

Twelve science teachers from one of the two summer professional development workshops participated in this study, and their demographic information is shown in Table 2. One of the middle school biology teachers was moving to high school biology for the school year following the workshop, and he considered this change in his choice of potential models of nanoscale phenomena for use in his classroom. 
Table 2: NCLT Professional Development Workshop Participants

\begin{tabular}{|c|c|c|c|c|c|}
\hline & Chemistry & Physics & $\begin{array}{c}\text { Chemistry and } \\
\text { Physics }\end{array}$ & Biology & General Science \\
\hline Middle School & 0 & 1 Male & 0 & 0 & 2 Male \\
\hline High School & 3 Female, 1 Male & 2 Male & 1 Female, 1 Male & 1Male & 0 \\
\hline
\end{tabular}

\section{Instructional Sequence}

The design of the modeling portion of the workshop had three basic components: (1) Explore teachers' conceptions of physical representation models and modeling; (2) Expand this knowledge by means of research literature readings, discussions, and collaborations with fellow teachers; (3) Have teachers apply their knowledge on science models to models of nanoscale phenomena. Each of these components is described in the following paragraphs.

The exploration of teachers' conceptions of models included written responses and discussions related to the following questions: (a) What is a model?; (b) How can models be used in science instruction?; (c) What criteria should be considered when choosing a model? These conceptions were further explored with the presentation of seven sets of models of the same science phenomenon (e.g., three different models of a molecule, three different models of the solar system; three different models of a virus). Teachers ranked the models within a set, and provided reasoning for their ranking, in terms of which they would use in their classroom. Small and large group discussions followed the activity.

The second component of the series of modeling activities used educational research literature to guide teacher conceptions of what is believed to be important when selecting models. Teachers read an article by Coll, ${ }^{7}$ which emphasized the importance of student-designed models. Members of the NCLT professional development team led discussions on the article. Then teachers were asked to revisit the list of criteria they had created in the previous activity, and modify it as they saw fit. Three groups of four teachers each refined their lists of criteria and shared it with the larger group.

In the final phase of the activities, teachers were directed to find and evaluate a model, according to the criteria that they created in the modeling discussions, of a nanoscale phenomenon that they would consider using in their classrooms. Teachers were given a week to complete the task. Questions on models in the context of instruction on nanoscale phenomena were discussed upon completion of their assignments: (a) How do the criteria used to choose a science model compare to the criteria used to choose a model of a nanoscale phenomenon?; (b) Why are models so important in teaching nanoscale concepts?; (c) How well do these example models of nanoscale phenomena support the understanding of nanoscale concepts?

During the week that teachers had to search for their nanoscale phenomena models, lessons and activities surrounding nanoscale concepts utilized physical representation models within a design- and inquiry-based setting. Table 3 provides a brief description of the primary models used in the professional development workshop as well as their classifications according to the Boulter \& Buckley $^{12}$ typology. 
Table 3: Description of NCLT Professional Development Workshop Models

\begin{tabular}{|c|c|c|}
\hline Model & Classification & Description \\
\hline $\begin{array}{l}\text { Student-designed } \\
\text { Lego Self- } \\
\text { Assembling System }\end{array}$ & $\begin{array}{l}\text { Concrete Material, } \\
\text { Dynamic: Stochastic }\end{array}$ & $\begin{array}{l}\text { Students create a unique self-assembling system by gluing } \\
\text { Velcro and magnets to Lego blocks using a constantly- } \\
\text { shaking cardboard box top to test their designs. }\end{array}$ \\
\hline $\begin{array}{l}\text { Molecular } \\
\text { Workbench } \\
\text { Simulations }\end{array}$ & $\begin{array}{l}\text { Visual Pictorial, } \\
\text { Dynamic: Stochastic }\end{array}$ & $\begin{array}{l}\text { Students complete a series of activities available through the } \\
\text { Concord Consortium that allows them to manipulate } \\
\text { molecular shape and charge as well as the temperature of the } \\
\text { environment, and observe the corresponding effects. }\end{array}$ \\
\hline Hopping Magnet & $\begin{array}{l}\text { Concrete Material, } \\
\text { Dynamic Stochastic }\end{array}$ & $\begin{array}{l}\text { Students use a refrigerator magnet to simulate a magnetic } \\
\text { force microscope. }\end{array}$ \\
\hline $\begin{array}{l}\text { Magnetic Force } \\
\text { Microscope }\end{array}$ & $\begin{array}{l}\text { Concrete Material, } \\
\text { Dynamic: Stochastic }\end{array}$ & Students create a magnetic probe to scan a magnetic surface. \\
\hline $\begin{array}{l}\text { Scanning Probe } \\
\text { Tips }\end{array}$ & $\begin{array}{l}\text { Concrete Material, } \\
\text { Static }\end{array}$ & $\begin{array}{l}\text { Students design their own scanning probe tip based on their } \\
\text { observations and interactions with model AFM scans. }\end{array}$ \\
\hline $\begin{array}{l}\text { Surface Scans on an } \\
\text { AFM }\end{array}$ & $\begin{array}{l}\text { Concrete Material, } \\
\text { Dynamic: Stochastic }\end{array}$ & $\begin{array}{l}\text { Students use their designed probe to scan a 3-dimensional } \\
\text { surface on a Lego } ® \text { board. }\end{array}$ \\
\hline $\begin{array}{l}\text { Cardboard Scanning } \\
\text { Probe Microscope }\end{array}$ & $\begin{array}{l}\text { Concrete Material, } \\
\text { Dynamic: Stochastic }\end{array}$ & $\begin{array}{l}\text { Students use their pointer finger as a probe to scan a } \\
\text { cardboard surface. }\end{array}$ \\
\hline $\begin{array}{l}\text { Machine-operated } \\
\text { Lego AFM }\end{array}$ & $\begin{array}{l}\text { Concrete Material, } \\
\text { Dynamic: } \\
\text { Deterministic }\end{array}$ & $\begin{array}{l}\text { Students examine a giant size working AFM created from } \\
\text { Legos®. }\end{array}$ \\
\hline Paper Buckyballs & $\begin{array}{l}\text { Concrete Material, } \\
\text { Static }\end{array}$ & $\begin{array}{l}\text { Students cut and fold paper models of a buckyball to create a } \\
\text { three-dimensional version. }\end{array}$ \\
\hline Soccer ball & $\begin{array}{l}\text { Concrete Material, } \\
\text { Static }\end{array}$ & $\begin{array}{l}\text { Students viewed the soccer ball as an example of the } \\
\text { hexagons and pentagons that comprise a buckyball. }\end{array}$ \\
\hline $\begin{array}{l}\text { Overhead } \\
\text { Nanotubes }\end{array}$ & $\begin{array}{l}\text { Concrete Material, } \\
\text { Static }\end{array}$ & $\begin{array}{l}\text { Using overhead transparencies, students can fold their } \\
\text { nanotube into a zigzag, arm-chair, or helical. }\end{array}$ \\
\hline Wire Nanotubes & $\begin{array}{l}\text { Concrete Material, } \\
\text { Static }\end{array}$ & Students fold chicken wire into large nanotubes. \\
\hline $\begin{array}{l}\text { Miniature Space } \\
\text { Elevator }\end{array}$ & $\begin{array}{l}\text { Concrete Material, } \\
\text { Dynamic: Stochastic }\end{array}$ & $\begin{array}{l}\text { Students create a composite using string and packing tape to } \\
\text { model the creation of a nanotube composite and test the } \\
\text { strength of their composite material. }\end{array}$ \\
\hline $\begin{array}{l}\text { Acting Out } \\
\text { Molecules in a } \\
\text { Solid, Liquid, and } \\
\text { Gas }\end{array}$ & $\begin{array}{l}\text { Gestural Bodily, } \\
\text { Dynamic: Stochastic }\end{array}$ & $\begin{array}{l}\text { Students hold hands and stand still to imitate solids, move } \\
\text { more freely to imitate liquids, and randomly move about to } \\
\text { imitate gases. }\end{array}$ \\
\hline
\end{tabular}

*The word student is used to mean whoever is completing the lesson. In the case of the professional development program, the teachers were considered the students.

As can be seen in the table, many models were used in the course of the workshop to support the nanoscale phenomena concepts being presented, and a balance existed between static and dynamic model types. Throughout the workshop, discussions of the lessons included a critique of the models as well as the design and inquiry activities surrounding the models.

\section{Data Collection and Analysis}

A variety of data sources were utilized to gain insight on the research questions. Small and large group conversations on models in general and nanoscale phenomena models were audio taped. 
Each audiotape was reviewed for themes. The first author wrote field notes to supplement the audio. Participants written responses to questions and their written notes taken in the journals were copied, and the nanoscale phenomena models found by teachers were documented. The first round of data analysis was conducted independently by the two authors. Each conducted multiple iterations of reading and reviewing the data. Each came up with tentative patterns and themes to organize the data, after which they collaborated on analysis.

The models found or created by teachers were categorized according to an adapted version of Boulter and Buckley's typology. ${ }^{12}$ The categories "Verbal Written/ Oral" and "Mathematical/ Formulaic" were eliminated from the categorizations as this study was focused on two- and three-dimensional physical representation models. Additionally, we chose not to report categorization according to "Mixed Mode/ Single Mode" or "Qualitative/ Quantitative." For the purposes of this study, classifying the models according to these categories did not add to the results.

\section{Findings}

\section{Model Criteria}

The pre-activity initial model criteria listed by teachers focused on the accuracy of the models related to science phenomena as well as how well the model fit into the purpose of the science lesson. Teachers also placed importance on the appearance of models, including color and size, and logistical issues involved, such as cost and durability. A few of the criteria listed concerned the student-relatability of the models.

After the model-ranking activity, many teachers added a criterion that related to studentinvolvement with the model, primarily by means of student-created models. Two teachers suggested that the model should invite "probing and investigation." The original criteria appeared to be focused on static models used for "show-and-tell"-type purposes.

Upon collaboration in groups, and the discussion of the Coll article on student-created models in science education, ${ }^{7}$ all of the teachers seemed convinced of the importance of allowing their students to create and critique their own and each other's models. The revised list of criteria generated by teachers were finalized after these discussions and summarized in Table 4 under headings that encapsulate the criteria. 
Table 4: Criteria Considered by Science Teachers When Choosing Models

\begin{tabular}{|c|c|}
\hline \multirow{2}{*}{$\begin{array}{l}\text { Physical Attributes } \\
\text { - Clearly visible } \\
\text { - Aesthetics } \\
\text { - Labels on model explaining parts and pieces } \\
\text { - Size } \\
\text { - Color } \\
\text { - 3-D vs. 2-D }\end{array}$} & $\begin{array}{l}\text { Student Involvement } \\
\text { - Invites and directs manipulation and investigation } \\
\text { - Student-designed } \\
\text { - Invites conversation or critique } \\
\text { - Level of possible student-interaction with model }\end{array}$ \\
\hline & $\begin{array}{l}\text { Logistics } \\
\text { - Cost } \\
\text { - Time }\end{array}$ \\
\hline \multirow{2}{*}{$\begin{array}{l}\text { Concepts } \\
\text { - Accurate representation of the conceptual goal } \\
\text { - Illustrates main ideas } \\
\text { - Ease of understanding } \\
\text { - Spatial accuracy } \\
\text { - Information delivery } \\
\text { - Purpose within lesson } \\
\text { - Minimizes potential misconceptions/ } \\
\text { discrepancies within the model }\end{array}$} & $\begin{array}{l}\text { - User-friendly } \\
\text { - Durability } \\
\text { - Spatial accuracy } \\
\text { - Grade-level of students }\end{array}$ \\
\hline & $\begin{array}{l}\text { Other } \\
\text { - Clear and concise verbal component } \\
\text { - More than one model per concept } \\
\text { - Ability to manipulate } \\
\text { - Engaging }\end{array}$ \\
\hline
\end{tabular}

The criteria selected by teachers encapsulated a range of topics including the physical look of a model, conceptual analogies, logistics of using the model, and student involvement possibilities related to the model. As indicated in the table, the teachers agreed that a number of criteria were important in selecting models; however, the priority placed on each criterion is not evident from their group-generated list.

\section{Teacher-Selected Models of Nanoscale Phenomena}

A range of science concepts was addressed in the models of nanoscale phenomena found by teachers. The models, a description, and their classification according to the Boulter \& Buckley typology ${ }^{12}$ are shown in Table 5.

Table 5. Teacher-Selected Models and Boulter \& Buckley Classifications

\begin{tabular}{|l|l|}
\hline Model & Model Classification \\
\hline Protein synthesis acted out by students & Gestural Bodily, Dynamic: Stochastic \\
\hline $\begin{array}{l}\text { Students create and manipulate a model surface area to } \\
\text { volume ratio }\end{array}$ & Concrete Material, Dynamic: Stochastic \\
\hline Drug delivery animation from the internet & Visual Pictorial, Dynamic: Deterministic \\
\hline $\begin{array}{l}\text { Model on dependence of the wavelength of emitted light } \\
\text { on nanoparticle size in the form of sound wavelength } \\
\text { from different heights of water in beakers }\end{array}$ & Concrete Material, Dynamic: Stochastic \\
\hline Internet image of buckyballs binding to Nanotubes & Visual Pictorial, Static \\
\hline $\begin{array}{l}\text { Student-made model of lithography with candy, called a } \\
\text { "nanosmore" }\end{array}$ & Concrete Material, Static \\
\hline Images of buckyballs and nanotubes & Visual Pictorial, Static \\
\hline Allotropes of carbon images & Visual Pictorial, Static \\
\hline Quantum dot image & Visual Pictorial, Static \\
\hline Electron size compared to proton & Visual Pictorial, Static \\
\hline $\begin{array}{l}\text { Simulation of nanotube properties as a result of } \\
\text { nanotube dimensions }\end{array}$ & Visual Pictorial, Dynamic: Stochastic \\
\hline SEM images & Visual Pictorial, Static \\
\hline
\end{tabular}


To consider trends in our sample, the total number of models of each type was totaled based on the classification shown in the above table. The models utilized by members of NCLT

professional development team serve as a comparison to the teacher-selected models as shown in Table 6.

Table 6. Teacher-Selected and NCLT Model Classifications

Teacher-Selected Models

\begin{tabular}{|l|c|c|c|}
\hline & Static & $\begin{array}{c}\text { Dynamic: } \\
\text { Deterministic }\end{array}$ & $\begin{array}{c}\text { Dynamic: } \\
\text { Stochastic }\end{array}$ \\
\hline $\begin{array}{l}\text { Concrete } \\
\text { Material }\end{array}$ & 1 & & 2 \\
\hline $\begin{array}{l}\text { Visual } \\
\text { Pictorial }\end{array}$ & 6 & 1 & 1 \\
\hline $\begin{array}{l}\text { Gestural } \\
\text { Bodily }\end{array}$ & & & 1 \\
\hline
\end{tabular}

NCLT Primary Workshop Models

\begin{tabular}{|l|c|c|c|}
\hline & Static & $\begin{array}{c}\text { Dynamic: } \\
\text { Deterministic }\end{array}$ & $\begin{array}{c}\text { Dynamic: } \\
\text { Stochastic }\end{array}$ \\
\hline $\begin{array}{l}\text { Concrete } \\
\text { Material }\end{array}$ & 5 & 1 & 6 \\
\hline $\begin{array}{l}\text { Visual } \\
\text { Pictorial }\end{array}$ & & & 1 \\
\hline $\begin{array}{l}\text { Gestural } \\
\text { Bodily }\end{array}$ & & & 1 \\
\hline
\end{tabular}

As is evident in the comparison, the professional development staff used a variety of dynamic models to supplement the static models. Over half of the models the teachers selected were static-type, six of which were visual pictorial models. Five of the models found by teachers were dynamic, and four of those had stochastic components.

All twelve teachers felt their models were a fairly good fit for the group-generated criteria. One teacher commented that he did not know how accurate his model was because he was not an expert on the structure of quantum dots. Because of this comment, the other teachers were asked if they felt they had a strong understanding of the concepts their models addressed. Ten said they did not do any additional background research on the topics of their models besides what they already knew. Six teachers felt that they already had a good understanding of the topic because they taught related concepts in their classrooms. Six teachers expressed that they did not know how accurate their models were, thus could not fully consider the accuracy criteria in the evaluation of their models.

Four of the models incorporated a level of student involvement because teachers intended their students to create the models themselves. The extent to which this creation was open-ended was unclear. In some cases, it seemed as if the teachers intended to provide specific instructions on how the models were to be created.

One teacher discussed his model with respect to its compatibility with inquiry learning. The other teachers did not discuss their models in the context of having students use them for investigative purposes.

\section{Discussion}

The teacher-generated list of criteria provided insight on the teachers' conceptions of models and their use in science instruction. The majority of responses related to accuracy and physical attributes of models and the logistics of using models. After discussion on an article of the role of models in science education, many teachers incorporated some potential form of student 
involvement as something they should consider when choosing models. This change in conception was also seen in the presentation of models of nanoscale phenomena as a few of the teachers chose models of nanoscale phenomena that their students could make and emphasized the importance of student-created handmade models. This result supports the idea that presenting science education research to teachers is one means to promote changes in the classroom. Finding a way to provide access and opportunities to connect to the science education research community as part of the NCLT professional development workshops could prove effective in motivating changes in the classroom.

The generated list of criteria placed emphasis on the accuracy of models, understanding misconceptions that could occur because of using models, and the learning discussions surrounding the use of models. However, many of the teachers acknowledged the fact that they did not investigate the science surrounding the models of nanoscale phenomena that they chose. This will influence our design and structure of the modeling assignment in the next round of professional development workshops. In the future, we will encourage teachers to first select a topic and find some general information about it, or provide them with some information on a few pre-selected topics in nanoscale science and challenge them to create or find a model that could be incorporated into a lesson on that topic. We were reminded in this experience that we cannot take for granted that teachers will have some pre-existing knowledge on nanoscale science concepts. One of the challenges we face in trying to incorporate nanoscience education into middle- and high-school classrooms is the nanoscience education of teachers. The selection and presentation of models of nanoscale phenomena rely on an understanding of the nanoscience concepts the model aims to present; the importance of the criteria associated with the discussions of accuracy and misconceptions surrounding models must be maintained in the selection of models of nanoscale phenomena.

Although the professional development team presented multiple models relating to each nanoscale concept, none of the teachers suggested the criteria were any different for models of nanoscale phenomena compared to science models in general. As put by one teacher, there were "no differences, since a model is used to represent difficult concepts regardless of scale." In their selection of a model, teachers selected one to represent a nanoscale concept. The nature of the directions of the assignment may have affected their choice of one model versus multiple models to represent a nanoscale phenomena concept. Upon reflecting on this issue, we do not want the selection of one model to be a limiting factor for teachers. Research has indicated that multiple models prove to be more effective with the presentation of abstract or non-observable concepts. The NCLT professional development team plans to continue this investigation of single versus multiple models to represent nanoscale phenomena during the course of future NCLT workshops as well as in middle- and high-school classrooms.

Throughout the course of the workshop, teachers seemed to place an increased importance on providing opportunities for their students to create models and critique them. There is, however, a difference between creating a model based on specific instructions and designing a model with more open-ended criteria. The extent to which the four teachers who proposed a student-created model intended their students to have an open-ended design opportunity is unclear. They emphasized student-made models, but did not emphasize the design nature these models could incorporate. In our future professional development workshops, we intend to discuss the 
differences between the creation and design of models, including the increased cognitive challenge for students in model design.

During the course of the workshop, we did not specifically encourage teachers to find models that could be used in inquiry-based lessons, but we frequently used models of nanoscale phenomena in our activities for inquiry purposes. Our demonstrations of inquiry with models of nanoscale phenomena did not seem to influence the models teachers chose, and while the groupgenerated list of criteria suggested it was important for a model to invite investigation, only one of the models was presented for use in an inquiry setting. It seemed that a conception held by many of the teachers was that inquiry and the use of models were two separate tools used in teaching science. In other words, the teachers did not view models as a way for students to collect data, make meaning of data, and generate understanding of a phenomenon. They viewed models primarily for "show-and-tell" purposes. Stochastic models tend to lend themselves to inquiry tasks, and the majority of teachers did not select this type of model. While we used models in our instruction of nanoscale concepts for the purpose of collecting data, determining patterns in data, and generating evidence-based explanations from data, we clearly did not emphasize well the role of models for conducting inquiry-based instruction. In the future, our professional development course will need to include instructional activities that facilitate teachers' understanding of how to use models to generate student understanding during inquirybased science investigations. The lack of incorporation of models into inquiry-based science lessons may limit student opportunities for the construction of knowledge, especially in nanoscale science and engineering education, since we believe there is a greater dependence on modeling in this area.

The discussion of the results contained some of the changes we intend to implement in our professional development activities surrounding models and their use in nanoscale science and engineering education. To summarize these changes, we plan to use a similar framework from our previous workshops, but provide teachers with a choice of nanoscale science and engineering topics and challenge them to gather some preliminary information about the one they are most interested in using in their classroom. From this, they will brainstorm the types of models that they believe would support their students' conceptions, and select or create one or more of these models. The professional development team will promote further discussions on the models used in our activities and highlight the models we chose and why. We also intend to provide additional literature on the use of models as tools for design and inquiry.

\section{Conclusions}

Science and engineering at the nanoscale level is an emerging field that has significant implications for the future of science and engineering education. As educators seek ways of infusing nanoscale concepts into existing science curricula, it becomes clear that we must design experiences to enhance teachers' science and engineering knowledge as well as their pedagogical content knowledge for teaching nanoscale concepts. Models unquestionably play a central role in nanoscale science and engineering education. At the same time that we realize the need for teachers' professional development, we must also take into account what learning sciences has told us for decades - that learners conceptions play a significant role in how the learner generates conceptual understanding. To this end, our study is a first step in examining teachers' 
conceptions of nanoscale models and the implications of these conceptions for the design of professional development on nanoscale science and engineering.

\section{References}

${ }^{1}$ National Nanotechnology Initiative. (2006) National Nanotechnology Initiative. Retreived December 2006 at http://nano.gov.

2 National Science Board. (2006). Science and Engineering Indicators, http://www.nsf.gov/statistics/seind06/

${ }^{3}$ Seymour, Elaine. 2001. Tracking the processes of change in U.S. undergraduate education in science, mathematics, engineering, and technology. Science Education, 86, 79 - 105.

${ }^{4}$ Douglas, J., Iverson, E. \& Kalyandurg, C. (2004). Engineering in the K-12 classroom: An analysis of current practices \& guidelines for the future. American Society for Engineering Education: Washington, DC.

${ }^{5}$ Iversen, E., Kalyandurg, C., \& de Lapeyrouse, S. (2004). Why k-12 engineering? Available online; http://www.engineeringk12.org/. Retrieved December 2006.

${ }^{6}$ Foley, E. T., \& Hersam, M. C. (2006). Assessing the need for nanotechnology education reform in the united states. Nanotechnology Law \& Business, 3(4), 467-484.

${ }^{7}$ Coll, R. (2005). The role of models/and analogies in science education: implications from research. International Journal of Science Education, 27(2), 183-198.

${ }^{8}$ National Center for Learning and Teaching in Nanoscale Science and Engineering (NCLT). (2006). Available online; http://www.nclt.us. Retreived July 2006.

${ }^{9}$ Stevens, S., Sutherland, L., Schank, P., \& Krajcik, J. (2007). The big ideas of nanoscience. Unpublished manuscript.

${ }^{10}$ Gilbert, J., \& Boulter, C. (2000). Developing models in science education. Dordrecht: Kluwer.

${ }^{11}$ Harrison, A. G., \& Treagust, D. F. (2000). A typology of school science models. International Journal of Science Education, 22(9), 1011-1026.

${ }^{12}$ Boulter, C., \& Buckley, B. (2000). Constructing a typology of models for science education. In Gilbert \& Boulter (2000) Developing models in science education. Dordrecht: Kluwer.

${ }^{13}$ Harrison, A. G., \& Treagust, D. F. (1996). Secondary students' mental models of atoms and molecules: Implications for teaching chemistry. Science Education, 80(5), 509-534.

${ }^{14}$ France, B. (2000). Biotechnology teaching models: What is their role in technology education? International Journal of Science Education, 22(9), 1027-1039.

${ }^{15}$ Gilbert, J. K., \& Osborne, R. J. (1980). The use of models in science and science teaching. European Journal of Science Education, 2(1), 3-13.

${ }^{16}$ Grosslight, X., Unger, C., Jay, E. and Smith, C. (1991) Understanding models and their use in science:

Conceptions of middle and high school students and experts. Journal of Research in Science Teaching, 28, 799-822.

${ }^{17}$ Treagust D. F., Harrison, A. G. and Venville, G. (1998) Teaching science effectively with analogies: An approach for pre-service and in-service teacher education. Journal of Science Teacher Education, 9, 85-101.

${ }^{18}$ ABET (Accreditation Board for Engineering and Technology). (2003). Criteria for Accrediting Engineering Programs (2003-2004).

${ }^{19}$ Bloom B. S. (1956). Taxonomy of educational objectives, handbook I: The cognitive domain. New York: David McKay Co Inc.

${ }^{20}$ Bell, P. (2004). On the theoretical breadth of design-based research in education. Educational Psychologist, 39 , 243-253. 